\title{
Pengaruh Konsumsi Tempe terhadap Kadar Gula darah pada Penderita Diabetes Melitus di Kelompok Senam Ibu-Ibu di Kelurahan Talang Banjar Jambi
}

\author{
Iin Indrawati ${ }^{1}$, Maimaznah ${ }^{2}$ \\ ${ }^{1,2}$ Program Studi D III Keperawatan Sekolah Tinggi ilmu Kesehatan Baiturrahim Jambi \\ Emai: iinian737497@gmail.com
}

\begin{abstract}
DM management that is more effective and efficient requires prevention and control programs that are on target. There are several risk factors associated with the incidence of DM, one of which is a behavioral factor. The behavior or lifestyle in question is eating habits. The purpose of this study was to determine the effect of tempe consumption on blood sugar levels of DM sufferers in the exercise groups of women in the Talang Banjar Village, Jambi.The research method used was a quasi-experimental one group pre and post experience test. The population is group of gymnastics mothers of gymnastics mothers who suffer from diabetes mellitus, amounting to 6 people, using total sampling techniques, and analyzed using $T$ Test.The analysis showed that there was no effect of tempe consumption with blood sugar levels with a p value ( $p$ value 0.201).Although the results of the study did not show any influence, it is likely that this was caused by several things such as the small number of samples, and it was not determined whether the $N$ sample was a type 1 or type 2 diabetes sufferer. diabetes mellitus as a controller or helps control blood sugar levels in the body.
\end{abstract}

Keywords: diabetes Mellitus, tempe

\begin{abstract}
Abstak
Penanggulangan DM yang lebih efektif dan efisien membutuhkan program pencegahan dan penanggulangan yang tepat sasaran.Ada beberapa faktor resiko yang berhubungan dengan kejadian DM, salah satunya adalah factor prilaku. Prilaku atau gaya hidup yang dimaksud adalah kebiasaan makan. Tujuan penelitian ini yaitu untuk mengetahui pengaruh konsumsi tempe terhadap kadar gula darah penderita DM di kelompok senam ibu-ibu di Kelurahan Talang Banjar Jambi. Metode penelitian yang digunakan adalah quasi eksperimen dengan one group pre and post tes experience. Populasinya adalah ibu-ibu kelompok senam ibu-ibu senam yang menderita diabetes mellitus yang berjumlah 6 orang, dengan menggunakan teknik total sampling, dan dianalisis dengan menggunakan uji $\mathrm{T}$ Test. Hasil analisis menunjukkan tidak ada pengaruh konsumsi tempe dengan kadar gula darah dengan nilai $\mathrm{p}$ ( $\mathrm{p}$ value 0,201 . Walaupun hasil penelitian tidak menunjukkan adanya pengaruh, kemungkinan hal ini disebabkan oleh beberapa hal seperti jumlah sampel yang sedikit, dan tidak ditentukannya apakah sampel Nmerupakan penderita diabetes tipe 1 atau tipe 2. Namun perlu diketahui bahwa tempe banyak manfaatnya dan dilansir mempunyai pengaruh yang positif terhadap penderita diabetes mellitus sebagai pengontrol atau membantu mengontrol kadar gula darah dalam tubuh.
\end{abstract}

Kata Kunci: diabetes Mellitus, tempe

\section{PENDAHULUAN}

DM dan komplikasinya telah menjadi masalah kesehatan masyarakat dan merupakan penyebab yang penting dari angka kematian, kesakitan dan kecacatan di dunia. Terdapat 382 juta orang yang hidup dengan DM di dunia, dan diperkirakan akan meningkat menjadi 592 jjuta orang pada tahun 2035. Diperkirakan dari 382 juta orang tersebut, terdapat 175 juta orang yang 
belum terdiagnosis sehingga terancam berkembang progresif menjadi komplikasi tanpa disadari dan tanpa pencegahan.DM di Indonesia telah menjadi masalah kesehatan yang cukup penting. Berdasarkan data epidemiologi diperkirakan bahwa pada tahun 2030 prevalensi diabetes mellitus di Indonesia mencapai 21,3 juta orang. 2 Meningkatnya prevalensi dan terjadinya komplikasi pada orang dengan DM menimbulkan kerugian yang sangat besar baik secara individual, maupun sector kesehatan secara keseluruhan. Biaya perawatan baik langsung maupun tidak langsung pada orang yang hidup dngan DM di yakini lebih besar dibandingkan dengan orang non DM. Selain itu dampak psikologis yang diakibatkan oleh komplikasi DM juga akan menyebabkan timbulnya masalah-masalah sosial.Orang dengan DM memiliki resiko mengalami penyakit jantung coroner 3,2 kali lebih besar dibandingkan non penderita, resiko mengalami stroke 2,9 kali lebih besar. Selain penyakit kardiovaskuler, DM juga merupakan salah satu penyebab utama penyakit ginjal, kebutaan dan amputasi pada usia dibawah 65 tahun. Dampak lain dari DM adalah mengurangi umur harapan hidup sebesar 5 - 10 tahun.

Penanggulangan DM yang efektif dan efisien membutuhkan program pencegahan dan penanggualangan yang tepat sasaran. Salah satu cara mencegahnya adalah dengan mengetahui karakteristik individu yang berisiko mengalami DM. Berdasarkan teori terdapat beberapa factor resiko yang berhubungan dengan kejadian DM, yaitu factor sosio demografi prilaku dan keadaan klinis atau mental individu. Faktor sosio demografi diantaranya adalah usia, jenis kelamin, pekerjaan, tingkat pendidikan dan status perkawinan. Prilaku atau gaya hidup yang dimaksud adalah kebiasaan makan, merokok dan aktifitas fisik. Sedangkan keadaan klinis atau mental adalah indeks massa tubuh, lingkar perut dan stress.DM merupakan gangguan metabolism karbohidrat ketika insulin tidak ada, tidak cukup, atau tidak efektif karena resistensi insulin.DM merupakan penyakit kronis karena defisiensi absolut atau relative atau resisten insulin. DM merupakan penyakit kronis yang umum terjadi pada dewasa yang membutuhkan supervise medis berkelanjutan dan edukasi perawatan mandiri pada pasien.Pengaturan diet harus memperhatikan berat tubuh dan aktivitas penderita DM guna menentukan besarnya kalori, adanya komplikasi penyakit lain, jenis dan jumlah makanan yang dikonsumsi.

Salah satu bahan pangan yang dapat dikembangkan untuk menangani diabetes adalah kedelai.kedelai telah diteliti memiliki efek hipoglikemik, yaitu dapat menurunkan kadar glukosa darah pada penderita diabetes. efek hipoglikemik kedelai diduga disebabkan gabungan berbagai mekanisme seperti pemacuan sekresi insulin, pengaturan pengaturan motilitas di usus, stimulasi ekspresi gen reseptor insulin, peningkatan sensitivitas jaringan terhadap insulin. Tempe merupakan salah satu makanan yang mengandung protein nabati.Tempe merupakan produk olahan kedelai yang kaya serat pangan (dietary fiber). Serat pangan ini berasal dari miselium kapang yang menghubungkan satu butiran kedelai dengan kedelai lainnya, membentuk suatu massa padat berwarna putih, kompak dan utuh. Kandungan serat pangan dalam tempe cukup tinggi, yaitu sekitar 8-10 g/100 g.

Tujuan penelitian ini adalah Mengetahui pengaruh konsumsi tempe terhadap kadar gula darah pada ibu-ibu kelompok senam lansia di Kelurahan Talang Banjar Kota Jambi.

\section{METODE PENELITIAN}

Desain yang digunakan dalam penelitian ini adalah Quasi eksperimen dengan Pretest-posttest control one group design. Di dalam model ini sebelum dimulai perlakuan kedua kelompok diberi 
tes awal berupa pengukuran kadar gula darah selanjutnya akan di ukur kembali kadar gula darahnya setelah intervensi dilakukan. Intervensi berupa pemberian / konsumsi tempe 300 gr perhari yang di bagi dalam 3 kali makan.selama satu minggu penuh (7 hari) baru setelah itu dilakukan kembali pengukuran kadar gula darah.Langkah-langkah pengumpulan data untuk kelompok intervensi sebagai berikut: 1)Mengumpulkan ibu-ibu penderita Diabetes melitus dan menjelaskan maksud serta tujuan tindakan yang akan dilakukan 2)Menjelaskan prosedur pelaksanaan tindakan, manfaat dan risikonya bahwa yang dilakukan merupakan kegiatan yang akan diteliti. 3)Setelah mendapatkan penjelasan, sampel diberikan kesempatan untuk menandatangani lembar persetujuan bila setuju 4)Peneliti mengisi lembar pemeriksaan/observasi yang telah disediakan, 5)Melakukan pemeriksaan gula darah sampel dalam kurun waktu 1 minggu dengan 2 kali pemeriksaan. 6)Mencatat hasil pemeriksaani sesudah pemeriksaan.

Penelitian dilakukan pada kelompok senam ibu-ibu di kelurahan Talang Banjar Kota jambi pada kurun waktu 12 bulan dimulai pada September 2017 sampai September 2018. Analisis data dengan menggunakan analisis bivariat. Dengan jumlah sampel sebanyak 6 orang.

\section{HASIL DAN PEMBAHASAN}

Pengaruh konsumsi tempe terhadap gula darah

Hasil pengukuran gula darah sebelum dan setelah diberikan konsumsi tempe, dapat dilihat pada table1 berikut ini :

Tabel 1. Pengaruh konsumsi tempe terhadap gula darah $(\mathbf{n}=7)$

\begin{tabular}{lcccc}
\hline \multicolumn{1}{c}{ Variabel } & Mean & $\begin{array}{c}\text { Standar } \\
\text { Deviation }\end{array}$ & $\begin{array}{c}\text { Standar } \\
\text { Error }\end{array}$ & $\begin{array}{c}\text { P- } \\
\text { Value }\end{array}$ \\
\hline $\begin{array}{l}\text { Gula darah sebelum konsumsi } \\
\text { tempe (Pre Test) }\end{array}$ & 250,000 & 81,54753 & 30,82207 & 0,201 \\
$\begin{array}{l}\text { Gula darah sesudah konsumsi } \\
\text { tempe(Post Test) }\end{array}$ & 216.056 & 68,05600 & 25,72275 & \\
\hline
\end{tabular}

Hasil analisis pada Tabel1 terjadi kesalahan dalam pelaksanaan

Menunjukan bahwa rata-rata gula darah penelitian seperti pengambilan jumlah setelah Pemberian setelah konsumsi tempe sampel yang terlalu kecil, tidak dipantaunya lebih tinggi dibandingkan dengan gula konsumsi harian para ibu dalam hal darah sebelum konsumsi tempe. Rata-rata konsumsi makanan harian selama proses perilaku gula darah sebelum konsumsi penelitian berlangsung. Tidak adanya tempe adalah 250,000, dan setelah pengkondisian yang ketat terhadap konsumsi tempe rata-rata gula darah konsumsi makanan lainnya dapat menjadi 216.056. Hasil statistik t-test menimbulkan bias pada uji coba yang didapatkan $p$-value $=0,201>0,05$, maka sedang dilakukan. Seperti yang telah dapat disimpulkan bahwa secara statistik disampaikan pada konsep teori sebelumnya tidak ada Pengaruh Pengaruh konsumsi bahwa tempe kaya akan nilai zat gizi baik tempe terhadap gula darah.

Pada hasil analisis uji statistik dapat ditunujukkan bahwa tidak ada pengaruh konsumsi tempe dengan kadar gula darah. Hal ini sebenarnya bukan berarti bahwa tempe tidak punya zat yang dapat berpengaruh terhadap kadar gula darah seseorang karena kemungkinannya bisa saja yang salah satunya.

Zat gizi yang berpengaruh dalam pengontrolan kadar gula darah seperti salah satu bahan pangan yang dapat dikembangkan untuk menangani diabetes adalah kedelai. kedelai telah diteliti memiliki efek hipoglikemik, yaitu dapat menurunkan kadar glukosa darah pada 
penderita diabetes. efek hipoglikemik kedelai diduga disebabkan gabungan berbagai mekanisme seperti pemacuan sekresi insulin, pengaturan pengaturan motilitas di usus, stimulasi ekspresi gen reseptor insulin, peningkatan sensitivitas jaringan terhadap insulin.Tempe merupakan salah satu makanan yang mengandung protein nabati.Tempe merupakan produk olahan kedelai yang kaya serat pangan (dietary fiber). Serat pangan ini berasal dari miselium kapang yang menghubungkan satu butiran kedelai dengan kedelai lainnya, membentuk suatu massa padat berwarna putih, kompak dan utuh. Kandungan serat pangan dalam tempe cukup tinggi, yaitu sekitar 8-10 g/100 g.i serat pangan.

Sebenarnya penderita penyakit ini tetap dapat hidup normal jika mereka menerapkan pengelolaan diabetes yang baik langkah-langkah yang mesti dilakukan oleh penderita diabetes mellitus di antaranya penurunan berat tubuh bagi yang kelebihan berat dan kegemukan, olah raga atau latihan secara teratur, pengaturan pola makan yang baik, menghindari stress dan memeriksakan kadar gula darahnya. Beberapa strategi tersebut, sudah ada yang menurunkan Diabetes namun hingga sekarang belum ada diet khusus untuk diabetes, yang ada adalah upaya menormalkan kembali kadar gula darah (60-120 mg/dL).

Salah satu cara untuk mencegah terjadinya DM yaitu dengan mengkonsumsi tempe minimal tiga potong ukuran sedang per hari dengan cara dikukus atau direbus untuk menjaga kandungan zat gizi dan komponen aktif tempe yang sangat berperan penting sebagai pencegah DM adalah isoflavon sebagai antioksidan, protein (khususnya asam amino arginin), inhibitor enzim $\alpha$-amilase, inhibitor enzim $\alpha$-amilase, inhibitor enzim $\alpha$-glukosidase, serat pangan (dietary fiber), dan saponin. semua komponen tersebut sangat bermanfaat untuk memperbaiki profil sel beta pankreas dalam memproduksi hormon insulin yang cukup untuk mencegah DM.
Hal ini sejalan dengan hasil penelitian oleh Utari, Rimbawan, Riyadi, Muhilal., dan Purwantyastuti (2011), yaitu diperoleh hasil yaitu analisis kadar protein menunjukkan bahwa dalam 100 gram tempe kukus mengandung $16,85 \% \mathrm{w} / \mathrm{w}$ protein, asam amino yang dominan pada tempe adalah arginin yang pada penelitian ini merupakan asam amino dengan kadar tertinggi $(6,58 \% \mathrm{w} / \mathrm{w})$. Hasil penelitian serupa oleh Suarsana et al (2010) menunjukkan bahwa pemberian ekstrak tempe pada kelompok tikus positif diabetes dapat mempertahan dan meningkatkan bobot badan tikus serta menurunkan kadar glukosa dalam darah tikus yang mengalami diabetes.

Mengingat baiknya konsumsi tempe pada penderita DM maka sebaiknya penderita DM tetap dianjurkan untuk mengkonsumsinya. Meskipun penelitian ini tidak menunjukkan hasil yang tidak berpengaruh.Ada baiknya penelitian ini ditindak lanjuti dengan menghindari factorfaktor perancu.

\section{SIMPULAN}

Tidak ada pengaruh konsumsi tempe terhadap kadar gula darah pada pasien Diabetes Melitus (DM) dengan nilai $p$ ( $p$ value 0,201 . Pentingnya konsumsi tempe di masyarakat dapat ditindaklanjuti menjadi penelitian lanjutan. Bagi penderita Diabetes Melitus (DM) untuk dapat mengkonsumsi tempe secara teratur sebagai salah satu konsumsi yang sehat

\section{DAFTAR PUSTAKA}

Astawan, M. (2008). Sehat dengan Tempe. Bogor: Dian Rakyat. ISBN: 979-523932-5

Astawan, M., Resdiyati, T., dan Maknun, L. (2017). Tempe: Sumber zat gizi dan komponen bioaktif untuk keksehatan. Bogor, IPB Press

Citerawati, Y. W. (2017). asesmen gizi tingkat lanjut. yogyakarta: transmedika 
Harrison. (2013). Endokrinologi dan Metabolisme. Alih Bahasa Hartono, A. Tangerang Selatan: KARISMA Publishing Grup

Hurst, M. (2015). Medical-Surgical Nursing Review.Vol 2. Belajar Mudah Keperawatan Medikal Bedah. Alih Bahasa Yulianti, D, Isneini, S. Jakarta: EGC. ISBN 978-979-044629

Lemone, P., Burke, K.M., dan Bauldoff, G. (2016). Buku Ajar Keperawatan Medikal Bedah: Gangguan Endokrin, Edisi 5. Alih Bahasa: Angelina, B., dkk.Jakarta: EGC

Robinson, J.M., dan Saputra, L. (2014). Buku Ajar : Visual Nursing (MedikalBedah). Sebuah Panduan Diagnosis Penyakit, Keterampilan, Serta Asuhan Keperawatan. Jilid 2. Alih Bahasa Ardiaria, M. Tangerang: Binarupa Aksara.

Saputra, L. (2014). Ilustrasi Bewarna Patofisiologi Penyakit untuk Perawat, Bidan, dan Paramedis. alih bahasa Esrada, R. tangerang selatan: Binarupa Aksara Publisher. ISBN 978-602-200-172-0

Utari, D.M., Rimbawan., Riyadi, H., Muhilal., dan Purwantyastuti. (2011). Potensi Asam Amino pada Tempe untuk Memperbaiki Profil Lipid dan Diabetes Mellitus. Jurnal Kesehatan Masyarakat Nasional, Vol 5, No.4.

Yulianto, W., A. (2018). pangan fungsional untuk kesehatan otak, jantung, gigi dan mulut, tulang, dan diet untuk diabetes, pelangsing tubuh, penecegahan kanker dan HIV. yogyakarta: CV Budi Utama 